\title{
Matter and Method in the Military Law Course
}

$\mathrm{T}$ HE establishment of the Students' Army Training Corps has given rise to many teaching problems. Each subject had had to be overhauled and has had to be taught by a different method. This not only because of the difference in the amount of time allowed, but also because of the discrepancy in the qualities of the students. The old regime has been temporarily revolutionized. The effects of the new régime will be visible upon the old long after educational institutions will have resumed their former leisurely way. The ending of the war, and the disestablishment of the S. A. T. C. will not abolish all the innovations which the Corps has introduced.

I have been giving a course in Military Law to S. A. T. C. men and I am eager to compare notes with other men in the field. The men whom we find in our S. A. T. C. courses vary in age from 18 to 46 . They are therefore considerably older than the students we were accustomed to in pre-war times. The men, moreover, are less likely to have come to us directly from the cloistered walls of a college or university. They have had, of course, some school training, and many college and university education. But there is an immediate and striking difference between these and our pre-war students, in that the latter had more book learning than experience of life, and the present students have more experience than book learning. The differences in age, book and life preparation are sufficient to call for a radical change in our method and matter. Add to these reasons the absorbing, compelling reason that results must be produced in a short time and you have the elements of a vital force which ought to transform the classroom - transform it in respect to the students and in respect to the teacher. The teacher must now use powers he had not much call for using before. His experience of life, his power to deal with practical situations, his ability to give the impression of a live wire, will strongly condition his success in class. For these men are alive; indeed, too much alive to satisfy academic requirements. The quiet and leisure of the grove are necessary elements in that wide and deep culture which it is the proud and grand object of the schools to supply. We are not here to develop culture. Our 
business is more immediate and more practical. We must make men capable of dealing with particular subject matters, and make them quickly. However, this does not entirely militate against our endeavoring to make men independent and original in thought and capable of grasping and dealing with a general situation through our inculcation of general principles and through our development of general powers of straight, rapid and vigorous thinking. We must overcome the torpor of their habitual mental life-as distinguished from their practical life-and adopt an interesting, even striking presentation of the subject.

The case method will not do. The time is short, the subject does not easily lend itself to it. To be successful the analytic method must have ample time in which to develop and must be employed in a fitting environment. How many of our students in pre-war times prepared the assignment intelligently? You can do little with a class that has not mastered the cases; and this mastery means a knowledge of the facts and the decisions of each case and in addition an attempt to synthesize the decisions of the assignment. In certain respects we can expect more in this regard from the new than from the old students, and in others we can expect less. The time limit, however, seems to be decisive. You can cover, once you are started on your career after the painful and elaborate preliminary steps, fifteen pages of the Government Manual for Courts-Martial every day. The facts so covered could not be developed by the case method in less than 150 or 200 pages.

A combination of methods seems to be the best. The case method may be used, but the hypothetical instance is given by the instructor in class. This is rapid and clear and interesting. You are not depending upon the vague possibility that the assignment will have been covered-barracks life is not conducive to reading; you are causing the students to use their minds since all co-operate in the endeavor to seek a solution. A text is assigned for preparation, and a discussion of that text is had in class. This discussion consists of questions on the text, and questions arising out of the text. Elaboration of obscure or diffcult points, and a summary of the discussion of the instructor in which he recapitulates the points, expounds the principles and interprets their meaning, completes the lesson. This lesson is not, however, a purely legal one. The dryness of the ordinary course in the law school is proverbial among students. Instruc- 
tors are the only ones who have not found that out. Or, if they have, they are not willing or capable of remedying the condition. Any one who has studied abroad knows that principles count and that these principles are the outcome not only of purely technical legal discussion but of a philosophic view of the subject of law. Criminal law, for instance, is not only a bare discussion of crimes and the procedure to punish them; but it is more: a probing into the sources of things, a delving into the reasons for the principles involved. We cannot go to this undefiled source until we have employed not only the crude instruments of law as we teach it but have risen higher into the sociological and philosophic realms and utilized the results of sociology, of political science, and of philosophy.

This is the opportunity of the instructor. He now has good material to work with. There are two methods of philosophic presentation: that which deals predominantly with matter which may be got from wide reading, and that which deals predominantly with matter which may be got from a wide experience of life. Not only the bald legal, technical reasons for things may now be given, but we may dive deep and soar high into domains which make the study of law not only a practical and useful subject but one which is fascinating and enduring as well.

The fact that the Government has been delayed in furnishing the Manual we were to use has not had altogether bad results. "Tutti $i$ male non vengono per nuocere". ('Tis an ill wind that blows no good.) Lectures were in disfavor, and we have had to adapt ourselves to a situation in which the student body was as I have described. At the outset we could have made three grand divisions of students: Those who had come to us directly from high schools, those who had come to us from colleges either immediately or remotely in time, and those who had had either high school or college education and were now well advanced in the high adventure of life. This class would have included all the rest. The method and matter would have differed in each case. But in the rush the segregation was not possible. Our problem then, since we had to take all the classes together was the problem of presenting averages. The public speaker meets the test of a mixed audience. We have had to confront the same task as he-that of appealing to all though each has had widely varying experiences from the others.

Academic life plays a much larger part-two-thirds-than 
strictly military life in the S. A. T. C. The problem of the reconciliation of the academic and the military presents itself. But, though the problem be acute and important, the reconciliation is not impossible. The object of the classroom is to form independent thinkers; the object of the drill field is to make automatons. It does seem ridiculous, from one aspect, to develop the side of mind which is to be completely subordinated in another field of operation. But the compartments may be kept separate. For the purpose of military efficiency he endeavors to forward team work; for the purpose of academic power he endeavors to cherish independence of thought. He subordinates and even suppresses himself in one case, and protrudes himself in the other. We must, therefore, at all costs strive to educe the latent original power of our students, and nurture those capacities which we already find to hand.

So much for method and the problems of the S. A. T. C. The matter of the course has been partly conditioned by the delay in the text books. Some of us have even had to beat time. The Government lately has gone so far as to recommend the suspension of the military course pertaining to Courts-Martial and the Laws of War, and devote the time of that course to the Army Regulations, which were to be taught by Military officers and to recommend this suspension on the ground that nothing of value could be accomplished without the textbook.

I shall indicate in the following pages the ground I traversed before taking up the Government Manual.

Lessons I. and II. (Lectures).

1. Importance of the subject for S. A. T. C. men.

a. Importance for all officers.

b. Importance for Judge Advocates.

c. Importance for Court-Martial officers.

2. Definition of Military Law. Divisions-Substantive law and procedure.

(1) Procedure.

a. Procedure previous to trial. General remarks.

b. Procedure at trial (Evidence).

c. Procedure after trial (Supervisory authority).

(2) Crimes. Definitions of crime, proof of and punishment for crime included in this subject.

Articles of War. What they are. The Divisions. Comparison with civil criminal law. 
(3) Martial law.

(4) Laws of War.

The importance of a strict adherence to international laws of war, and to laws of humanity. Robert E. Lee as the type of fair and humane warrior. Compare with the Germans in this war, and condemn practices against humanity.

(5) Military Government. Law of Occupation of conquered territory.

(6) Comparative Military Law.

Comparison of procedure of Courts Martial and of substantive law of military crimes of France and of America.

3. Distinctions between Military Law and Army Regulations and herein of the difference between disciplinary and administrative measures.

4. Distinctions between Military Law and Customs of the Service. Military law written, Customs unwritten.

5. Division of labor. Lessons to be given on the following branches the indicated number of times:

$\begin{array}{ll}\text { Procedure } & 9 \\ \text { Penal Law } & 6 \\ \text { Forms } & 5 \\ \text { Martial Law } & 1 \\ \begin{array}{l}\text { Military Govern- } \\ \quad \text { ment }\end{array} & 2 \\ \text { International } & \\ \text { Law of War } & 2 \\ \text { Comparative Mili- } & \\ \quad \text { tary law } & 1\end{array}$

6. General principle dominating the Army. The subordination of military to civil power.

a. President Wilson in his note to Germany in October, pointing out that the civil power was subordinate to the military in that country and that we could not deal with such a government.

b. The history of the doctrine. Its application.

c. The Roman Republic and the Roman Empire. The subordination in the former of the military authority and the boast of the Romans that the majestic 
toga of the civil officer had greater respect paid to it than the military cloak of the tribune.

d. Example from recent happenings in an allied country. Prime Minister Lloyd George and General Maurice. The dismissal of Maurice the triumph of the civil power over the military.

III. Recitation. Facts and principles brought out by question and answer, by discussion, and by summary exposition and interpretation by the instructor. The following lessons were conducted in the same way.

The Concept of Law.

1. What it is.

2. In science.

3. In morals.

4. In law.

5. Distinguishing characteristics of law in all these cases:

(1) a norm, rule of universal application;

(2) a penalty attached to the breach of it.

6. In what respects do the sanctions differ in these three cases.

IV. Criminal Law.

1. The divisions of law.

2. The place of criminal law in the legal system.

3. The place of military law in that system.

4. What is criminal law. The difference between public and private wrongs. The basis for different procedure and different sanctions. Case of contract contrasted with that of assault. All the elements in which the cases differ brought out.

V. History of Public Wrongs.

1. Substantive Law.

(1) Primitive communities.

(2) Development, in England especially. The stages:

a. The law of tooth and fang. Private warfare and vengeance.

b. Compensation. The stepping in of the state to protect individuals and through them the group. Sociological and practical reasons for the process. 
2. Procedure.

(1) Trials.

(a) Early form of. Wager of battle, ordeals by fire and water. Later forms of trial.

(2) The relation between prosecution and trial.

(a) The private form of prosecution, beginning with the time when men took the law into their own hands, continuing through the time when crime became a public matter, and maintaining its existence even where the law of crime as a public wrong is highly developed, e. g., in England, where prosecution is to a certain extent private.

(b) Comparison with American public prosecutions. Fully public as the wrong public.

(c) Comparison with France. Private prosecution in addition to public. The private prosecutor has a voice in prosecution at trial, while in England he has not, though a private prosecutor exists.

3. Courts-martial.

(1) Comparison with and application to courts-martial.

(2) The divisions here; and the functions of prosecution.

(3) Substantive and Procedural law.

(4) History of Military Law in America.

\section{Criminal Intent.}

1. In general.

2. Specific intent.

3. General intent. Intent to commit felony and murder takes place. No specific intent to murder.

4. No intent. Responsibility based upon negligence. Development of this form of criminal responsibility. Upon what is it based-sociological and philosophical considerations.

5. Cases.

(1) Assault with intent to commit it. Individual in full possession of faculties.

(2) Insanity. Can an insane person be held responsible? Guilty, not guilty, guilty but insane.

(3) Intention to do an act, knowing the state of a man. Members of S. A. T. C. inoculated and the alleged criminal knows they were, and heedlessly injures arm of one of these. Is he guilty? Two ques- 
tions: (1) Whether knowledge is sufficient; a question of law; (2) Question of fact: Whether the effects of violence were reasonably to be anticipated.

4. Intention to do an act, not knowing the state of a person. Injury to arm; is there guilt here? Should alleged criminal have known condition of S. A. T.C. man's arm?

The place of imprudence, recklessness, heedlessness, and negligence in Criminal Law.

5. Drunkenness.

6. Application of the doctrines of specific and general intent and of responsibility with no intent.

(It is to be noted that the cases are given first in succession. Each one is discussed singly and in relation to the others. By the inductive process the principles applicable in each case are educed and elucidated.)

VII. Sources of Military Law and Relations Between Federal Courts and Courts-Martial.

1. Sources of Federal Courts. Constitution provides for Supreme Court, and gives Congress authority to provide for inferior courts.

2. Sources of military courts in constitutional provisions:

(1) Amendment $V$ to Constitution.

(2) Authority given to President as Commander in Chief.

(3) Powers of Congress. Art. 1, Sec. 7.

Congress-source of authority for federal courts (except Supreme Court) and for Military Courts.

4. Limitations on Federal power.

(1) Can Congress provide for any procedure of Military Court, or for any punishment? Cf. powers with regard to ordinary laws.

(2) The limitations upon Congress by the Constitution.

(3) The doctrine of unconstitutionality.

(a) The departments of government; their functions.

(b) The Federal Courts. The interpretative powers.

(c) The origin of the doctrine (a) Marbury v. Madison, (b) the authority of reason. 
5. Relation between Federal Courts and Courts-Martial.

(1) First contact between Federal Court and Court-Martial.

(a) Court-Martial not supreme, but may be called to account by Federal Court for lack of jurisdiction by writ of habeas corpus.

(b) What habeas corpus is. Its origin; its use.

(2) Second contact. Unconstitutional acts of CourtsMartial may be reversed and annulled by Federal Courts. The stream can rise no higher than its source. The source of Courts-Martial being Congress, the unconstitutional action of Congress cannot free the Court-Martial of constitutional limitations.*

Robert Ferrari.

New York City.

* "For the practical work of procedure a mock court-martial was prepared. The plot was invented, the characters were cast, and the testimony was in part presented. Rumors of demobilization prevented further progress. But this method was the best, it seems to me, by which, in the absence of text-books, information could be communicated. Even with a text-book the subject matter, as law teachers who have taken up the course this term will testify, is obscure to the students-and to the instructor! The trial makes the procedure interesting, concrete, clear, vivid and enduring. Indeed, it is probably the sole method of communicating the knowledge at all. During the trial the comparative features of military law are steadily kept in view, and similarities with and differences from the French procedure are pointed out. I attended a great many courts-martial in France in 19161917, and had this invaluable advantage." 